\title{
Polyphenol and flavonoid profiles and radical scavenging activity in leafy vegetable Amaranthus gangeticus
}

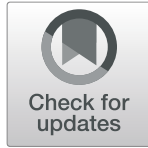

Umakanta Sarker $^{1^{*}}$ (D) and Shinya Oba ${ }^{2}$

\begin{abstract}
Background: Red amaranth (Amaranthus gangeticus L.) has great diversity in Bangladesh, India, and South East Asia with multipurpose uses. The bright red-violet colored A. gangeticus is a popular and low-cost leafy vegetable in the Asian continent including Bangladesh and India because of attractive leaf color, taste, adequate nutraceuticals, phenolic compounds, and sole source of betalains. The natural colors and phenolic compounds of this species have a significant role in promoting the health-benefit including the scavenging capacity of radicals, the colorant of food products, and play a vital role in the industry of foods. However, phenolic profiles and radical scavenging activity of this species have not been evaluated. Hence, for the first time, four selected advance lines of $A$. gangeticus were characterized for phenolic profiles, antioxidant constituents, and antioxidant potentiality.

Results: A. gangeticus genotypes are abundant sources of phenolic profiles and antioxidant constituents with good radical quenching capacity that differed across the genotypes. Twenty-five phenolic acids and flavonoids, such as protocatechuic acid, salicylic acid, gentisic acid, gallic acid, $\beta$-resorcylic acid, vanillic acid, $p$-hydroxybenzoic acid, chlorogenic acid, ellagic acid, syringic acid, ferulic acid, kaempferol, $m$-coumaric acid, trans-cinnamic acid, quercetin, p-coumaric acid, apigenin, caffeic acid, rutin, sinapic acid, isoquercetin, naringenin, myricetin, catechin, and hyperoside were identified in A. gangeticus accessions. A. gangeticus accessions LS7 and LS9 demonstrated ample phenolic acids, flavonoids, antioxidant constituents, and antioxidant potentiality. It revealed from the correlation study that antioxidant components of $A$. gangeticus genotypes exhibited good radical scavenging activities. The genotypes LS7 and LS9 could be directly used as phenolic profiles, antioxidant constituents, and antioxidant activity enrich cultivars.

Conclusions: The identified compounds of phenolic acids and flavonoids in A. gangeticus privilege the comprehensive study of pharmacology. The basic information on phenolic profiles and antioxidant constituents achieved in the present study will provide the scientist's forum for the scientific assessment of these compounds in A. gangeticus.
\end{abstract}

Keywords: A. gangeticus, Phenolic profiles, Flavonoids, Antioxidant activity, HPLC-UV, LC-MS-ESI, DPPH and ABTS assays

\footnotetext{
* Correspondence: umakanta@bsmrau.edu.bd

'Department of Genetics and Plant Breeding, Faculty of Agriculture,

Bangabandhu Sheikh Mujibur Rahman Agricultural University, Gazipur-1706, Bangladesh

Full list of author information is available at the end of the article
}

(C) The Author(s). 2020 Open Access This article is licensed under a Creative Commons Attribution 4.0 International License, which permits use, sharing, adaptation, distribution and reproduction in any medium or format, as long as you give appropriate credit to the original author(s) and the source, provide a link to the Creative Commons licence, and indicate if changes were made. The images or other third party material in this article are included in the article's Creative Commons licence, unless indicated otherwise in a credit line to the material. If material is not included in the article's Creative Commons licence and your intended use is not permitted by statutory regulation or exceeds the permitted use, you will need to obtain permission directly from the copyright holder. To view a copy of this licence, visit http://creativecommons.org/licenses/by/4.0/ The Creative Commons Public Domain Dedication waiver (http://creativecommons.org/publicdomain/zero/1.0/) applies to the data made available in this article, unless otherwise stated in a credit line to the data. 


\section{Background}

The genus Amaranthus is a fast-growing $\mathrm{C}_{4}$ plant with versatile uses such as ornamental plants, vegetables, and grains. It has wider acclimatization and distributed worldwide including Africa, America, Asia, Australia, and Europe. Edible stems and leaves of different Amaranthus species are cheap vegetables containing good protein with lysine and methionine, dietary fiber [1-3], vitamins [4, 5], carotenoids, and minerals [6-8]. It also contains natural pigments [9-11]; natural phytochemicals, such as flavonoids, phenolic acids, and vitamins [12-15]. The above compounds have remarkable contributions to the industry of food as these compounds quench reactive oxygen species (ROS) in the human body and give protection against several diseases including neurodegenerative diseases, cancer, cardiovascular diseases, cataracts, emphysema, retinopathy, atherosclerosis, and arthritis [16-20]. These compounds also have a significant role in promoting the health-benefit and food colorants [21]. The species of this genus are tolerant of salinity [22-24] and drought stress [25-28].

Amaranthus gangeticus has high diversity in Bangladesh, India, and Asia [29] with multiple utilities. The selected genotypes are bright red-violet and maroon color due to the presence of abundant betalain. It is an inexpensive and famous leafy vegetable in the Asian continent including Bangladesh and India because of attractive leaf color, taste, and high nutritional value. In Bangladesh, A. gangeticus is grown throughout the year including a period of scarcity of leafy vegetables from the end of winter to the start of summer $[1,2]$. A. gangeticus leaves inhibited the proliferation of colon (Caco-2) cancer cell lines, breast (MCF-7), and liver (HepG2) and exhibited anticancer potential [30].

Plants can be successfully engineered as biofactories for synthesizing biomolecules such as phenolic compounds, antioxidants, flavonoids, and vitamins having industrial and pharmaceutical interest; these efforts need the optimization of the above-mentioned biochemical knowledge to improve large-scale production, streamline the development of new products and make agribusiness increasingly competitive [31]. In the current decades, researches on food science are focused on polyphenols of plant origin, their antioxidant potentiality, accessibility in diets, and roles of protecting deadly diseases such as cardiovascular diseases, cancer, and neuro-degenerative [32]. Phenolic compounds are plant substances that possess in a common and aromatic ring bearing one or more hydroxyl groups. Flavonoids are the largest group of naturally occurring phenolic compounds, which occur in different plant parts both in a free state and as glycosides [33, 34]. Antioxidants of natural origin, such as phenolic components and vitamins are available in fruits and vegetables and protect against several diseases [35]. Phenolic components of plant origin can be classified into phenolic acids or simple phenols (hydroxycinnamic acids and hydroxybenzoic acids), tannins, flavonoids, and lignins that are involved in antioxidant potentiality, bitterness, color, flavor, acerbic taste, and odorness [36]. Antioxidant compounds reduce oxidative damage to the human body through inhibition of the oxidizing chain reactions caused by free radical [37]. Flavonoids and phenolic compounds are natural antioxidants, which can act as free radical scavengers [34]. Quercetin quenches free radicals to prevent the oxidation of low-density lipoprotein [38]. Ellagic acid has health-promoting effects due to its anticarcinogenic and antimutagenic responses [39].

Total phenolic content and antioxidant activity of $A$. gangeticus have already been reported [40]. However, there is little information available in the literature regarding the phenolic composition of this plant. Currently, the research group is evaluating the chances of utilizing A. gangeticus phenolic profiles, antioxidant constituents, as it has abundant natural potent antioxidants of interest in the food industry $[18,20]$. Based on yields and antioxidant activity, $A$. gangeticus genotypes were previously screened and the best four high yielding and antioxidant potential genotypes LS3, LS5, LS7, and LS9 were selected as advanced lines. It is the first attempt to study the phenolic profiles, antioxidant constituents, and antioxidant capacity in $A$. gangeticus. Hence, in this study, phenolic profiles, antioxidant constituents, and antioxidant potentiality of selected four advanced lines of A. gangeticus leafy vegetables were characterized in detail using high-performance liquid chromatography (HPLC) and liquid chromatography-mass spectrometry (LC-MS). The results of the present study improve the understanding of vitamins, phenolic, and flavonoids compounds and the antioxidant potentiality of A. gangeticus leafy vegetables for the food industry, nutritionists, pharmacists, and consumers.

\section{Methods}

\section{Experimental materials}

The seeds of four advance genotypes were collected from the Department of Genetics and Plant Breeding.

\section{Design and layout}

A completely randomized block design (RCBD) was used to execute the experiment at Bangabandhu Sheikh Mujibur Rahman Agricultural University with three replicates. The seeds of each genotype were sown in the ambient field of $1 \mathrm{~m}^{2}$ experimental plot following $20 \mathrm{~cm}$ and $5 \mathrm{~cm}$ distance between rows and plants, respectively. 


\section{Climatic and edaphic conditions and intercultural practices}

The site falls under the subtropical zone and has mean temperatures of $29^{\circ} \mathrm{C}$ (summer) and $18{ }^{\circ} \mathrm{C}$ (winter). There was no precipitation during the cropping season. The soil characteristics are silty clay, a little acidic $(\mathrm{pH}$ 6.4) with low content of organic matter (0.87\%). The compost (10 ton/ha) was applied at the time of preparation of lands. Gypsum, MP, TSP, and Urea were applied @ 30, 150, 100, and $200 \mathrm{~kg} / \mathrm{ha}$, respectively [41]. Proper intercultural operations were continued. For maintaining the exact spacing of plants in a row, proper thinning was executed. Weeds of experimental plots were regularly removed through proper weeding and hoeing. Regular irrigation was provided in the experimental plots for maintaining the proper growth of leafy vegetable amaranth. The leaf samples were collected from 10 randomly selected plants of each experimental plot at 30 days old plant (vegetative stage).

\section{Solvents and reagents}

Methanol, acetic acid (HPLC grade), acetonitrile (HPLC grade), acetone, standard phenolic compounds, 2, 2dipyridyl, dithiothreitol (DTT), DPPH (2, 2-diphenyl1picrylhydrazyl), standard Trolox, ABTS, gallic acid, aluminum chloride hexahydrate, Folin-Ciocalteu reagent, potassium acetate, rutin, sodium carbonate, and potassium persulfate. All solvents and reagents were bought from Merck (Germany) and Kanto Chemical Co. Inc. (Tokyo, Japan).

\section{Samples extraction for HPLC and LC-MS analysis}

The leaf samples were extracted by adding $10 \mathrm{~mL}$ methanol (80\%) containing acetic acid (1\%) in $1 \mathrm{~g}$ of leaves. The mixture was thoroughly homogenized. Then the mixture was kept in a test tube $(50 \mathrm{~mL})$ and capped tightly. The test tube was shaken in a shaker (Scientific Industries Inc., USA) for $15 \mathrm{~h}$ at $400 \mathrm{rpm}$. Finally, the extract was centrifuged for $15 \mathrm{~min}$ at $10,000 \times \mathrm{g}$ and filtered through a $0.45 \mu \mathrm{m}$ filter. The phenolic compounds were analyzed from the final filtrate. All extractions were performed in triplicate independent samples.

\section{Determination of phenolics through HPLC}

The HPLC method previously described by Sarker \& Oba $[11,28]$ was used to determine phenolic profiles in A. gangeticus leaf samples. Shimadzu SCL10Avp (Kyoto, Japan) HPLC was equipped with a binary pump (LC10Avp), a degasser (DGU-14A), and a Shimadzu detector (SPD-10Avp UV-Vis). Flavonoids and phenolic acids were separated using a column [CTO-10 AC (STR ODS-II, $150 \times 4.6$ mm I.D., (Kyoto, Japan)] [11]. The binary mobile phase was pumped with solvent A (6\% v/v acetic acid) in water and solvent $B$ (acetonitrile) at the flow rate of $1 \mathrm{~mL} / \mathrm{min}$ for $70 \mathrm{~min}$. HPLC system was run using a gradient program with $0-15 \%$ acetonitrile for 45 min, $15-30 \%$ for $15 \mathrm{~min}, 30-50 \%$ for $5 \mathrm{~min}$, and $50-$ $100 \%$ for $5 \mathrm{~min}$. Thirty-five ${ }^{\circ} \mathrm{C}$ temperature in the column was maintained with a $10 \mu \mathrm{L}$ volume of injection [11]. The detector was set at 360, 370, 280, and $254 \mathrm{~nm}$, respectively for continuous monitoring of flavonoids, cinnamic acids, and benzoic acids. For identification of the compounds, retention time and UV-vis spectra were compared with their respective standards. The confirmation of flavonoids and phenolic acids were performed through the mass spectrometry assay method. HPLC detected total compounds were represented as a total phenolic index (TPI). The previously described method of Sarker \& Oba [11, 28] was used to calculate TPI from the HPLC data. All samples were prepared and analyzed in duplicate. Phenolic compounds were estimated as $\mu \mathrm{g}$ $\mathrm{g}^{-1}$ FW. A mass spectrometer (AccuTOF, Japan) equipped with HPLC (Agilent 1100 Series) and a detector (UV-Vis) attached on-line with an ESI to analyze the spectrometric masses in negative ion mode maintaining the column elutes range of $\mathrm{m} / \mathrm{z}$ 0-1000 and needle voltage at $-2000 \mathrm{~V}$. Extract constituents were identified by LC-MS-ESI analysis.

\section{Quantification of phenolic compounds}

The respective standards of calibration curves were used to quantify each phenolic compound. We dissolved 25 phenolic compounds in $80 \%$ methanol as stock solutions to the final concentration of $100 \mathrm{mg} / \mathrm{mL}$. Respective standard curves $(10,20,40,60,80$, and $100 \mathrm{mg} / \mathrm{mL})$ were used to quantify the individual phenolic compounds with external standards. UV spectral characteristics, retention times, and co-chromatography of samples spiked with commercially available standards were applied for identification and match the phenolics. The phenolic compounds were quantified estimating the area of peak of corresponding standards.

\section{Estimation of pro-vitamin A}

The pro-vitamin A was estimated following our previously described method [7, 14]. The fresh leaf samples $(0.5 \mathrm{~g}$ each) were extracted with adding acetone $(10 \mathrm{~mL}$, $80 \%$ ) followed by centrifugation for $3-4 \mathrm{~min}$ at 10 , $000 \times$ g. A spectrophotometer was set at $510 \mathrm{~nm}$ and $480 \mathrm{~nm}$, respectively to read the absorbance. The results were calculated as mg pro-vitamin A per $100 \mathrm{~g}$ FW.

$$
\begin{aligned}
\text { Pro }- \text { vitamin } \mathrm{A} & =\left\{7.6\left(\mathrm{~A}_{480}\right)-1.49\left(\mathrm{~A}_{510}\right)\right\} \\
& \times \text { Final volume } /\{1000 \times \text { weight of leaf }(\text { fresh })\}
\end{aligned}
$$

\section{Estimation of vitamin C}

Vitamin $C$ was estimated following our previously described method $[14,42]$ by pre-incubation of samples 
using Dithiothreitol. Ascorbate reduced ferric ion to ferrous ion. 2, 2-dipyridyl bound with reduced ferrous ion to form complexes. A spectrophotometer was set at 525 $\mathrm{nm}$ to read the absorbance of $\mathrm{Fe}^{2+}$ complexes. Vitamin $\mathrm{C}$ was calculated in $\mathrm{mg} 100 \mathrm{~g}^{-1} \mathrm{FW}$.

\section{Extraction of samples for TP, TF, and TAC}

A. gangeticus leaves were collected at 30 days old plant. The collected leaves were air-dried in a shady place. 40 $\mathrm{mL}$ methanol (90\%) was utilized to extract samples from $1 \mathrm{~g}$ of fresh leaves (for TF) and dried leaf powder (for TF and TAC) of each accession in a capped test tube. The test tubes were shaken in a Thomastant T-N22S (Japan) water bath shaker for $1 \mathrm{~h}$. Finally, the extract was centrifuged for $15 \mathrm{~min}$ at $10,000 \times \mathrm{g}$ and filtered through a $0.45 \mu \mathrm{m}$ filter. The TAC, TF, and TP were estimated from the filtered extract.

\section{Estimation of total polyphenols}

The estimation of total polyphenols was carried out according to Sarker \& Oba [43, 44] and Jimenez-Aguilar \& Grusak [45] using Folin-Ciocalteau reagent. A microplate reader was set to detect the optical density at 740 $\mathrm{nm}$. The results were estimated as $\mu \mathrm{g} \mathrm{GAE} \mathrm{g}^{-1} \mathrm{FW}$.

\section{Estimation of total flavonoids}

Estimation of flavonoids was carried out according to the method described by Jimenez-Aguilar \& Grusak [45] using $\mathrm{AlCl} 3$. A microplate reader was set to detect the optical density at $500 \mathrm{~nm}$. The results were estimated as $\mu \mathrm{g}$ RE $\mathrm{g}^{-1} \mathrm{DW}$.

\section{Radical quenching capacity assay}

The antioxidant activity was estimated following the DPPH radical quenching assay [46, 47] and the ABTS method [48]. The absorbance was read at 517 (DPPH) and 734 (ABTS) nm using a Hitachi spectrophotometer (Japan). The antioxidant capacity (ABTS and DPPH) was measured according to the following equation:

$$
\mathrm{AC}(\%)=\left(\mathrm{A}_{\mathrm{b}}-\mathrm{A}_{\mathrm{s}} / \mathrm{A}_{\mathrm{b}}\right) \times 100
$$

Where, $\mathrm{AC}=$ antioxidant capacity, $\mathrm{A}_{\mathrm{b}}=$ absorbance of the blank sample [10 and $150 \mu \mathrm{L}$ methanol for $\mathrm{DPPH}$ and ABTS, respectively as a substitute of leaf extract], and $\mathrm{A}_{\mathrm{s}}=$ absorbance of the test compound. The results were calculated as $\mu \mathrm{g}$ TEAC $\mathrm{g}^{-1} \mathrm{DW}$.

\section{Statistical analysis}

The analysis of ANOVA was performed from mean data using software namely Statistix $8[49,50]$. The Mean separation was carried out following DMRT $(P<0.01)$. The results indicated as mean $\pm \mathrm{SD}$.

\section{Results}

\section{Flavonoids and phenolic acids}

The data on main fragment ions in $\mathrm{MS}^{2}$, identified compounds, $\lambda \max$, the molecular ion, and retention time are presented in Table 1. The flavonoids and phenolic acid data from four genotypes (LS3, LS5, LS7, and LS9) separated by liquid chromatography were compared with standard masses of phenolics and their respective peaks. Twenty-five flavonoid and phenolic acids such as protocatechuic acid, vanillic acid, gallic acid, salicylic acid, gentisic acid, $p$-hydroxybenzoic acid, $\beta$-resorcylic acid, syringic acid, ellagic acid, $m$-coumaric acid, trans-cinnamic acid, caffeic acid, chlorogenic acid, ferulic acid, sinapic acid, $p$-coumaric acid, rutin, naringenin, kaempferol, myricetin, catechin, isoquercetin, apigenin, hyperoside, and quercetin were detected in $A$. gangeticus. Across the compounds, seven compounds were identified as cinnamic acids, nine compounds were identified as benzoic acids, and nine compounds were identified as flavonoids compounds. Concerning three main classes of phenolics, the most prominent compounds were identified in four advance lines of $A$. gangeticus genotypes in the order: benzoic acids $>$ cinnamic acids $>$ flavonoids.

\section{Benzoic acids}

The most available phenolic acids were salicylic acids. The rest of the benzoic acids were identified in the following order: ellagic acid < syringic acid $<\beta$-resorcylic acid $p$-hydroxybenzoic acid $<$ gentisic acid $<$ protocatechuic acid < vanillic acid < gallic acid (Fig. 1 ).

The range of vanillic acid, gentisic acid, salicylic acid, gallic acid, $\beta$-resorcylic acid, syringic acid, and ellagic acid were 5.88 to $13.24,3.27$ to $9.78,7.87$ to $22.43,4.74$ to $14.76,1.86$ to $7.26,2.85$ to 6.36 , and 1.35 to $4.08 \mu \mathrm{g}$ $\mathrm{g}^{-1} \mathrm{FW}$, individually (Fig. 1). The maximum vanillic acid $\left(13.24 \mu \mathrm{gg}^{-1} \mathrm{FW}\right)$, gentisic acid $\left(9.78 \mu \mathrm{g} \mathrm{g}^{-1} \mathrm{FW}\right)$, salicylic acid $\left(22.43 \mu \mathrm{gg}^{-1} \mathrm{FW}\right)$, gallic acid $\left(14.76 \mu \mathrm{gg}^{-1}\right.$ FW), $\beta$-resorcylic acid $\left(7.26 \mu \mathrm{gg}^{-1} \mathrm{FW}\right)$, syringic acid $\left(6.36 \mu \mathrm{g} \mathrm{g}^{-1} \mathrm{FW}\right)$, and ellagic acid $\left(4.08 \mu \mathrm{gg}^{-1} \mathrm{FW}\right)$ were recorded in LS7. In contrast, the genotype LS5 showed the lowest vanillic acid $\left(5.88 \mu \mathrm{gg}^{-1} \mathrm{FW}\right)$, gallic acid (4.74 $\left.\mu \mathrm{g} \mathrm{g}^{-1} \mathrm{FW}\right)$, and the genotype LS3 had the lowest salicylic acid $\left(7.87 \mu \mathrm{g} \mathrm{g}^{-1} \mathrm{FW}\right)$, gentisic acid $\left(3.27 \mu \mathrm{g} \mathrm{g}^{-1}\right.$ FW), $\beta$-resorcylic acid $\left(1.86 \mu \mathrm{gg}^{-1} \mathrm{FW}\right)$, syringic acid

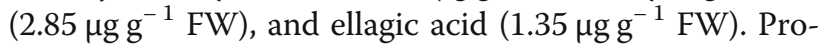
tocatechuic acid and $p$-hydroxybenzoic acid ranged from 3.65 to 11.68 and 1.65 to $7.64 \mu \mathrm{g} \mathrm{g}^{-1} \mathrm{FW}$, individually (Fig. 1). LS9 demonstrated the maximum protocatechuic acid $\left(11.68 \mu \mathrm{gg}^{-1} \mathrm{FW}\right)$ and $p$-hydroxybenzoic acid (7.64 $\left.\mathrm{\mu g} \mathrm{g}^{-1} \mathrm{FW}\right)$, whereas, LS5 demonstrated the minimum protocatechuic acid $\left(3.65 \mu \mathrm{g} \mathrm{g}^{-1} \mathrm{FW}\right)$ and $p$-hydroxybenzoic acid $\left(1.65 \mu \mathrm{g} \mathrm{g}^{-1} \mathrm{FW}\right)$. 
Table 1 Retention time (Rt), wavelengths of maximum absorption in the visible region $\left(\lambda_{\max }\right.$ ), mass spectral data, and tentative identification of phenolic compounds in four selected A. gangeticus leafy vegetables

\begin{tabular}{|c|c|c|c|c|c|}
\hline Peak no & $\begin{array}{l}\text { Rt } \\
(\min )\end{array}$ & $\lambda_{\max }(\mathrm{nm})$ & $\begin{array}{l}\text { Molecular ion } \\
{[\mathrm{M}-\mathrm{H}]^{-}} \\
(\mathrm{m} / \mathrm{z})\end{array}$ & $\begin{array}{l}M S^{2} \\
(\mathrm{~m} / \mathrm{z})\end{array}$ & Identity of tentative compounds \\
\hline 1 & 9.12 & 254 & 169.1354 & 169.1465 & 3,4,5 Trihydroxybenzoic acid \\
\hline 2 & 30.61 & 254 & 167.1423 & 167.1634 & 4-Hydroxy-3-methoxy benzoic acid \\
\hline 3 & 34.82 & 254 & 197.1125 & 197.1125 & 3,5-Dimethoxy-4-hydroxybenzoic acid \\
\hline 4 & 31.52 & 254 & 137.0325 & 137.0425 & 4-Hydroxybenzoic acid \\
\hline 5 & 48.23 & 254 & 137.2216 & 137.3241 & 2-Hydroxybenzoic acid \\
\hline 6 & 52.51 & 254 & 301.0384 & 301.0586 & $\begin{array}{l}\text { 2,3,7,8-Tetrahydroxy-chromeno }[5,4,3 \text {-cde }] \\
\text { chromene-5,10-dione }\end{array}$ \\
\hline 7 & 2.24 & 280 & 154.1342 & 154.1452 & 3,4-Dihydroxybenzoic acid \\
\hline 8 & 4.13 & 280 & 154.1354 & 154.1387 & 2,4-Dihydroxybenzoic acid \\
\hline 9 & 3.71 & 280 & 154.1357 & 154.1456 & 2,5- Dihydroxybenzoic acid \\
\hline 10 & 32.12 & 280 & 179.0792 & 179.0748 & 3,4-Dihydroxy-trans-cinnamate \\
\hline 11 & 31.14 & 280 & 353.1352 & 353.1453 & 3-(3,4-Dihydroxy cinnamoyl) quinic acid \\
\hline 12 & 42.16 & 280 & 163.0586 & 163.1105 & 4-Hydroxy cinnamic acid \\
\hline 13 & 47.95 & 280 & 193.1843 & 193.1748 & 3-Methoxy-4-hydroxy cinnamic acid \\
\hline 14 & 49.61 & 280 & 163.2621 & 163.2784 & 3-Hydroxy cinnamic acid \\
\hline 15 & 49.14 & 280 & 223.1632 & 223.1752 & 4-Hydroxy-3,5-dimethoxy cinnamic acid \\
\hline 16 & 67.32 & 280 & 147.1214 & 147.1143 & 3-Phenyl acrylic acid \\
\hline 17 & 23.93 & 280 & 290.2368 & 290.2246 & $\begin{array}{l}\text { (2R-3S)-2-(3,4-dihydroxyphenyl) } \\
\text {-3,4-dihydro-2-chromene-3,5,7-triol }\end{array}$ \\
\hline 18 & 26.73 & 280 & 271.0746 & 271.1527 & Naringenin \\
\hline 19 & 54.35 & 360 & 463.2795 & 463.3345 & Quercetin-3-O-glucoside \\
\hline 20 & 53.32 & 360 & 463.4428 & 463.5243 & Quercetin-3-O-galactoside \\
\hline 21 & 53.34 & 360 & 609.3788 & 609.3687 & Quercetin-3-O-rutinoside \\
\hline 22 & 7.56 & 370 & 301.0425 & 301.0348 & $\begin{array}{l}\text { 2-(3,4-dihydroxy phenyl) } \\
\text {-3,5,7-trihydroxychromene-4-one }\end{array}$ \\
\hline 23 & 4.61 & 370 & 626.1954 & 626.2675 & Myricetin-3-O-rutinoside \\
\hline 24 & 15.45 & 370 & 270.3426 & 270.3548 & $\begin{array}{l}\text { 4',5,7-Trihydroxyflavone, 5,7-Dihydroxy } \\
\text {-2-(4-hydroxyphenyl)-4-benzopyrone }\end{array}$ \\
\hline 25 & 17.82 & 370 & 593.5214 & 593.3264 & kaempferol-3-O-rutinoside \\
\hline
\end{tabular}

\section{Cinnamic acids}

Chlorogenic acid was identified as the most prominent compound within cinnamic acids followed by trans-cinnamic acid, sinapic acid, and ferulic acid (Fig. 2). A. gangeticus genotypes demonstrated ample cinnamic acids. The range of chlorogenic acid, trans-cinnamic acid, sinapic acid, $p$-coumaric acid, and ferulic acid was 8.86 to $15.38,5.52$ to $11.85,4.26$ to $8.35,4.72$ to 7.20 , and 3.51 to $5.16 \mu \mathrm{gg}^{-1} \mathrm{FW}$, individually (Fig. 2). The maximum trans-cinnamic acid, chlorogenic acid, sinapic acid, ferulic acid, and $p$-coumaric acid (15.38, 11.85, $8.35,7.20$, and $5.16 \mu \mathrm{g} \mathrm{g}^{-1} \mathrm{FW}$, individually) were noted in LS7. Whereas, LS3 exhibited the minimum chlorogenic acid and trans-cinnamic acid $\left(8.86\right.$ and $5.52 \mu \mathrm{g} \mathrm{g}^{-1}$ FW) and LS5 demonstrated the minimum sinapic acid, ferulic acid, and $p$-coumaric acid (4.26, 4.72, and $3.51 \mu \mathrm{g}$ $\left.\mathrm{g}^{-1} \mathrm{FW}\right)$. The range of $m$-coumaric acid and caffeic acid was 2.67 to 6.13 and 2.56 to $6.65 \mu^{g^{-1}}$ FW (Fig. 2). The maximum $m$-coumaric acid and caffeic acid (6.13 and

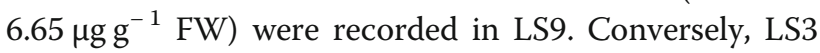
had the lowest $m$-coumaric acid and caffeic acid (2.67 and $\left.2.56 \mu \mathrm{g} \mathrm{g}^{-1} \mathrm{FW}\right)$.

\section{Flavonoids}

In this study, A. gangeticus genotypes demonstrated ample flavonoids such as rutin, naringenin, isoquercetin, quercetin, myricetin, kaempferol, apigenin, hyperoside, and catechin. Rutin, naringenin, isoquercetin, quercetin, myricetin, kaempferol, apigenin, hyperoside, and catechin varied from 6.73 to $9.62,2.24$ to $7.14,3.15$ to 6.98 , 3.62 to $6.35,3.72$ to $5.48,2.02$ to $4.88,2.21$ to $4.37,1.05$ to 2.35 , and 1.12 to $3.78 \mu \mathrm{g} \mathrm{g}^{-1} \mathrm{FW}$, individually (Fig. 3). 


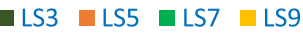

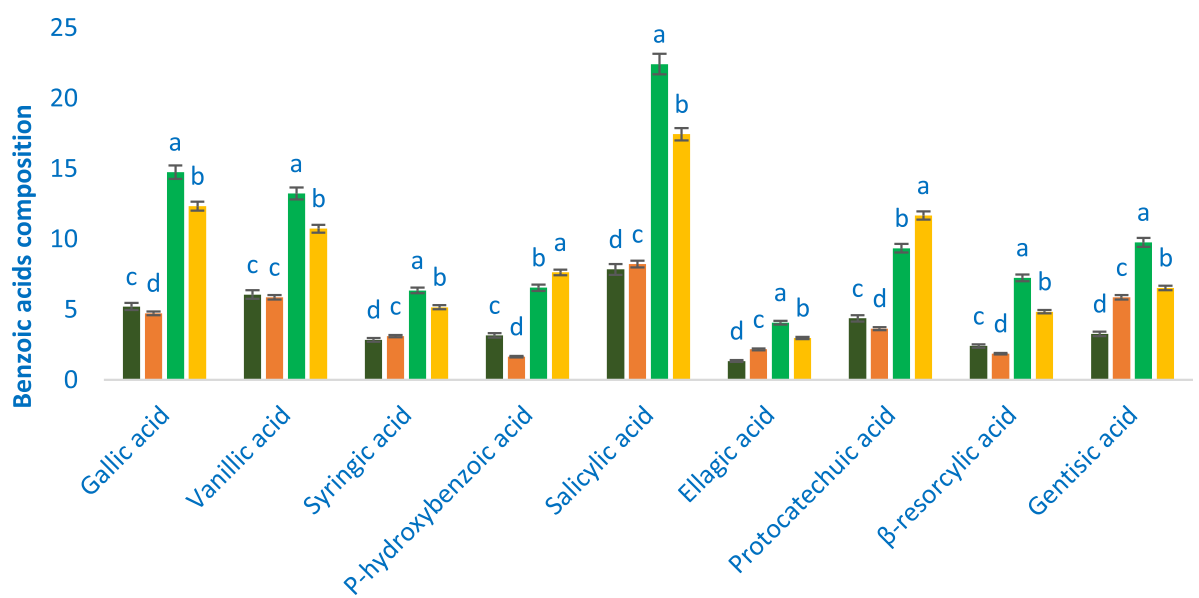

Fig. 1 Benzoic acids profile $\left(\mu \mathrm{g} \mathrm{g}^{-1} \mathrm{FW}\right)$ in four selected A. gangeticus leafy vegetables, in the bar different letters are significantly differed by DMRT, $(n=3),(P<0.01)$

The accession LS7 demonstrated the maximum rutin, naringenin, isoquercetin, quercetin, myricetin, kaempferol, apigenin, hyperoside, and catechin $(9.62,7.14,6.98$, $6.35,5.48,4.37,2.35$, and $3.78 \mu \mathrm{gg}^{-1} \mathrm{FW}$, respectively). Hyperoside content of LS7 had statistical similarity with LS9. The accessions LS5 and LS3 demonstrated high myricetin (4.22 and $\left.4.18 \mu \mathrm{g} \mathrm{g}^{-1} \mathrm{FW}\right)$, the accessions LS5 and LS9 demonstrated high rutin $\left(8.89\right.$ and $7.89 \mu \mathrm{g} \mathrm{g}^{-1}$ FW), the accessions LS5 demonstrated high quercetin $\left(5.32 \mu \mathrm{g} \mathrm{g}^{-1} \mathrm{FW}\right)$, and the accession LS3 demonstrated high isoquercetin and hyperoside (4.23 and $2.15 \mathrm{\mu g} \mathrm{g}^{-1}$ FW). In contrast, the accession LS9 demonstrated the minimum quercetin and myricetin (3.62 and $3.72 \mu \mathrm{g} \mathrm{g}^{-1}$ FW), the accession LS3 exhibited the minimum rutin and catechin (6.73 and $\left.1.12 \mu \mathrm{g} \mathrm{g}^{-1} \mathrm{FW}\right)$, and the accession LS5 exhibited the minimum isoquercetin, naringenin, apigenin, kaempferol, and hyperoside (3.15, $2.24, \quad 2.21,2.02$, and $1.05 \mathrm{\mu g} \mathrm{g}^{-1} \mathrm{FW}$, respectively) (Fig. 3).

\section{Phenolic fractions}

The range of total phenolic index (TPI), total cinnamic acids (TCA), total benzoic acids (TBA), total flavonoids (TF), and total phenolic acids (TPA) were 103.58 to 204.03, 36.10 to $59.27,36.59$ to $93.81,30.89$ to 50.95 , and 72.69 to $153.08 \mu \mathrm{g} \mathrm{g}^{-1} \mathrm{FW}$, individually (Fig. 4). The accession LS7 showed the maximum TPI $\left(204.03 \mu \mathrm{g} \mathrm{g}^{-1}\right.$ FW), TCA (59.27 $\left.\mathrm{gg} \mathrm{g}^{-1} \mathrm{FW}\right), \mathrm{TBA}\left(93.81 \mu \mathrm{gg}^{-1} \mathrm{FW}\right)$, TPA $\left(153.08{\mu \mathrm{gg}^{-1}} \mathrm{FW}\right)$, and TF $\left(50.95 \mu \mathrm{gg}^{-1} \mathrm{FW}\right)$. The TF of the accession LS3 and LS5 had statistical

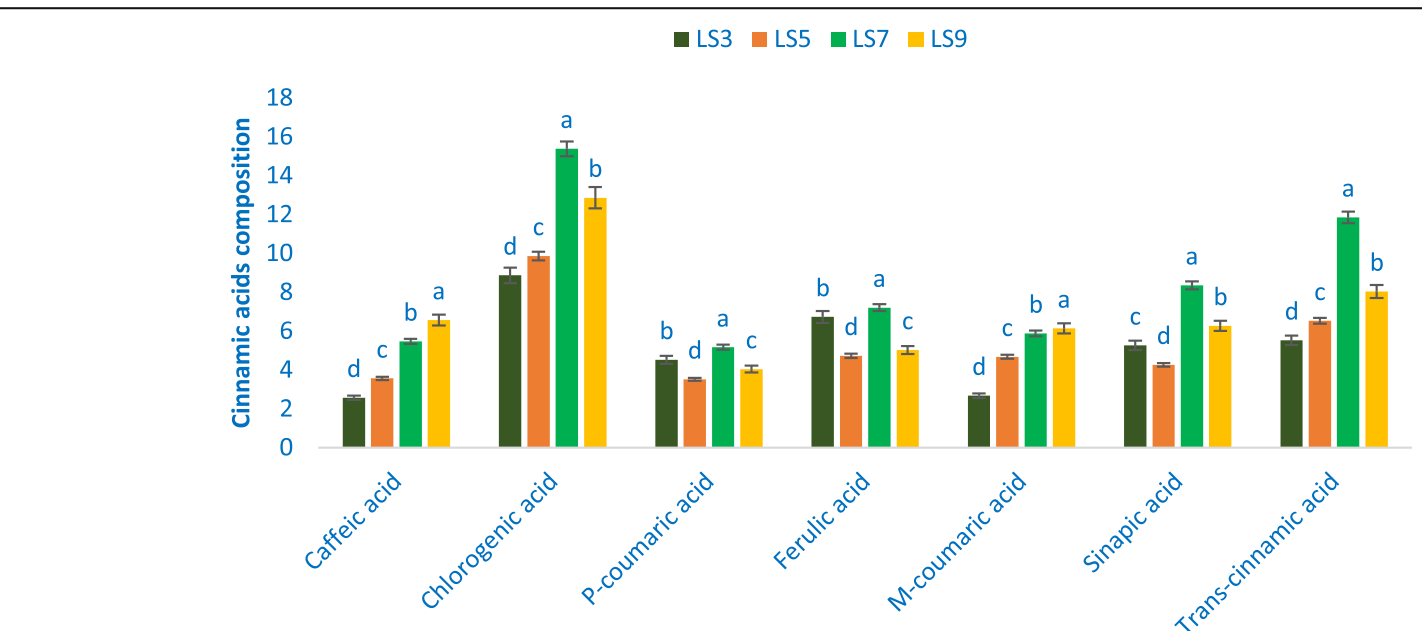

Fig. 2 Cinnamic acids profile ( $\mu \mathrm{g} \mathrm{g}^{-1} \mathrm{FW}$ ) in four selected $A$. gangeticus leafy vegetables, in the bar different letters are significantly differed by DMRT, $(n=3),(P<0.01)$ 


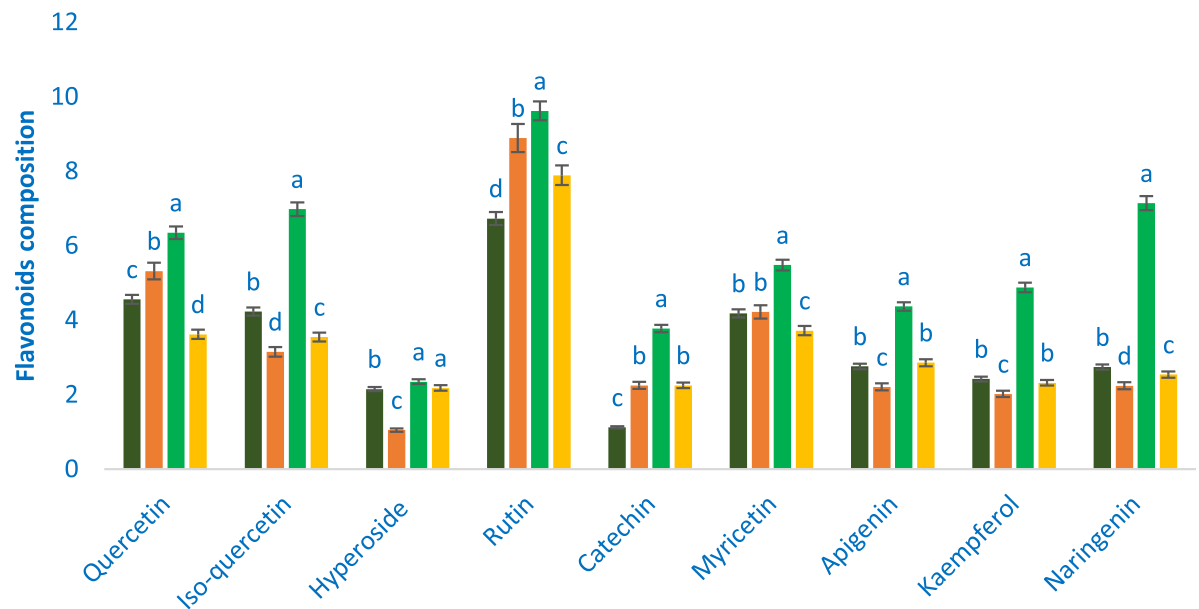

Fig. 3 Flavonoids profile $\left(\mu \mathrm{g} \mathrm{g}^{-1} \mathrm{FW}\right.$ ) in four selected A. gangeticus leafy vegetables, in the bar different letters are significantly differed by DMRT, $(n=3),(P<0.01)$

similarity to the accession of LS9. Conversely, the accessions LS3 and LS5 demonstrated the minimum TF (30.89, $\left.31.35 \mu \mathrm{g} \mathrm{g}^{-1} \mathrm{FW}\right)$, TCA $\left(36.10,37.10 \mu \mathrm{g} \mathrm{g}^{-1} \mathrm{FW}\right)$, TBA $\left(36.59, \quad 37.18{\mu g^{-1}}^{-1}\right.$ FW), and TPI (103.58, $\left.105.63 \mu \mathrm{g} \mathrm{g}^{-1} \mathrm{FW}\right)$. The accession LS3 demonstrated the minimum TPA (72.69 $\mathrm{\mu g} \mathrm{g}^{-1} \mathrm{FW}$ ) (Fig. 4).

\section{Antioxidant constituents and radical quenching capacity} $\mathrm{TP}$, pro-vitamin $\mathrm{A}$, vitamin $\mathrm{C}, \mathrm{AC}$, and $\mathrm{TF}$ differed significantly regarding the advance lines of $A$. gangeticus accession (Fig. 5). The range of pro-vitamin A content was $33.62 \mathrm{mg} 100 \mathrm{~g}^{-1}$ in LS3 to $72.34 \mathrm{mg}$ $100 \mathrm{~g}^{-1}$ in LS7. The accession LS7 demonstrated the maximum pro-vitamin A and LS9 exhibited high pro-vitamin A content. The range of vitamin $\mathrm{C}$ content was $72.45 \mathrm{mg} 100 \mathrm{~g}^{-1}$ in LS3 to $156.34 \mathrm{mg} 100$

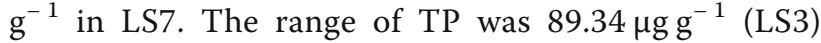

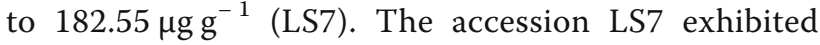
the maximum total polyphenols followed by LS9. TF exhibited prominent variation regarding genotypes with a range of $154.89 \mu \mathrm{g} \mathrm{g}^{-1}$ in LS5 to $280.44 \mu \mathrm{g} \mathrm{g}^{-1}$ in LS7. The range of antioxidant capacity (DPPH)

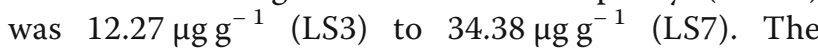
maximum antioxidant capacity (DPPH) was recorded in LS7 followed by LS9 and LS5. In contrast, LS3 demonstrated the minimum antioxidant capacity $(\mathrm{DPPH})$. The range of antioxidant capacity (ABTS) was $26.69 \mu \mathrm{gg}^{-1}$ to $68.89 \mu \mathrm{g} \mathrm{g}^{-1}$. The A. gangeticus advance line LS7 demonstrated the maximum antioxidant capacity (ABTS) followed by LS9. In contrast, antioxidant capacity (ABTS) was the minimum in LS3.

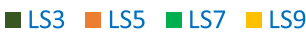

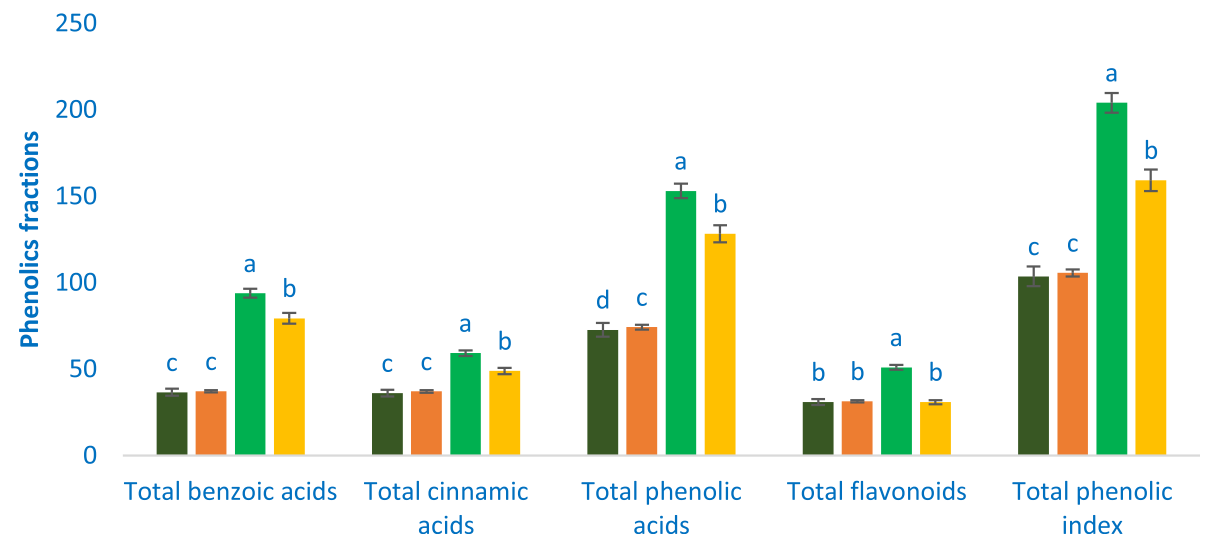

Fig. 4 Phenolic fractions composition $\left(\mu \mathrm{g} \mathrm{g}^{-1} \mathrm{FW}\right.$ ) in four selected A. gangeticus leafy vegetables, in the bar different letters are significantly differed by DMRT, $(n=3),(P<0.01)$ 


\section{口LS3 $\quad$ LS5 $\quad$ LS7 $\quad$ LS9}

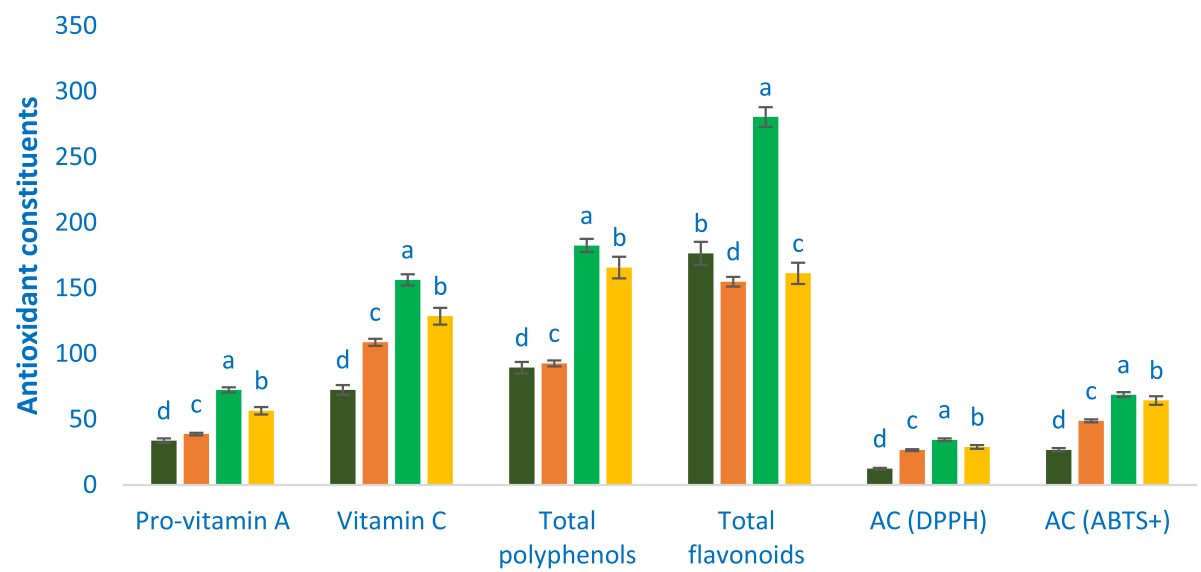

Fig. 5 Antioxidant constituents and quenching ability of free radicals in four selected A. gangeticus, Pro-vitamin A (mg $\left.100 \mathrm{~g}^{-1} \mathrm{FW}\right)$, TP ( $\mu \mathrm{g}$ GE $\mathrm{g}^{-1} \mathrm{FW}$ ), Vitamin C (mg $\left.100 \mathrm{~g}^{-1} \mathrm{FW}\right), \mathrm{TF}\left(\mu \mathrm{g} R \mathrm{~g}^{-1} \mathrm{DW}\right), \mathrm{AC}(\mathrm{DPPH})=$ antioxidant capacity (DPPH) $\left(\mu \mathrm{g} \mathrm{TEAC} \mathrm{g}^{-1} \mathrm{DW}\right), \mathrm{AC}(\mathrm{ABTS})=$ antioxidant capacity (ABTS) ( $\left.\mu \mathrm{g} \mathrm{TEAC} \mathrm{g}^{-1} \mathrm{DW}\right)$, in the bar different letters are significantly differed by DMRT, $(n=3),(P<0.01)$

\section{Correlation coefficient study}

The correlation of antioxidant constituents and the antioxidant capacity of A. gangeticus are shown in Table 2. Pro-vitamin A and vitamin $\mathrm{C}$ had significant positive interrelationships with vitamins, TP, TF, AC (DPPH and ABTS). A significant correlation among TP, TF, AC (DPPH and ABTS) were observed. Similarly, AC (ABTS) was significantly interrelated with AC (DPPH).

\section{Discussion}

Vitamins including pro-vitamin A and Vitamin C, flavonoids, and polyphenol compounds from natural origins, such as vegetables and fruits serve as antioxidants and protect against several diseases [35]. Recently, food researchers and consumers are interested in vitamins, polyphenols, and flavonoids of plant origin, their antioxidant potentiality, accessibility in diets, and roles of protecting deadly diseases such as cardiovascular diseases, cancer, and neuro-degenerative [32]. Phenolic compounds are plant substances that possess in a common and aromatic ring bearing one or more hydroxyl groups. Flavonoids are the largest group of naturally occurring phenolic compounds, which occur in different plant parts both in a free state and as glycosides [33, 34].Antioxidants compounds reduce oxidative damage to the human body through inhibition of the oxidizing chain reactions caused by free radical [37]. The shikimic acid pathway transformed phenylalanine and tyrosine into phenolic acids and flavonoids in plants [51]. Flavonoids have important biological functions in the human body. Quercetin quenches free radicals to prevent the oxidation of low-density lipoprotein [38]. Ellagic acid has health-promoting effects due to its anticarcinogenic and antimutagenic responses [39].

The analysis of variance revealed a wide range of variability of the studied traits regarding selected advance genotypes of $A$. gangeticus. A wide range of variability of the studied traits was also reported in $A$. tricolor and $A$. lividus [11], rice [52-65], maize [66-68], and coconut [69]. By the liquid chromatography assay, twenty-five flavonoid and phenolic compounds such as protocatechuic acid, vanillic acid, gallic acid, salicylic acid, gentisic acid, $p$-hydroxybenzoic acid, $\beta$-resorcylic acid, syringic acid, ellagic acid, $m$-coumaric acid, trans-cinnamic acid,

Table 2 The correlation coefficient for antioxidant constituents and radical quenching capacity in four selected A. gangeticus leafy vegetables

\begin{tabular}{|c|c|c|c|c|c|c|}
\hline & $\begin{array}{l}\text { Pro-vitamin A } \\
\left(\mathrm{mg} 100 \mathrm{~g}^{-1} \mathrm{FW}\right)\end{array}$ & $\begin{array}{l}\text { Vitamin C } \\
\left(\mathrm{mg} 100 \mathrm{~g}^{-1} \mathrm{FW}\right)\end{array}$ & $\begin{array}{l}\text { Total polyphenols } \\
\left(\text { GAE } \mu \mathrm{g} \mathrm{g}^{-1} \mathrm{FW}\right)\end{array}$ & $\begin{array}{l}\text { Total flavonoids } \\
\left.\text { (RE } \mu \mathrm{g} \mathrm{g}^{-1} \mathrm{DW}\right)\end{array}$ & $\begin{array}{l}\text { AC (DPPH) } \\
\left(\text { TEAC } \mu g^{-1} \text { DW) }\right.\end{array}$ & $\begin{array}{l}\text { AC }\left(\mathrm{ABTS}^{+}\right) \\
\left(\mathrm{TEAC} \mu \mathrm{g} \mathrm{g} \mathrm{g}^{-1} \mathrm{DW}\right)\end{array}$ \\
\hline Pro-vitamin A & & $0.65^{\mathrm{b}}$ & $0.74^{\mathrm{b}}$ & $0.96^{\mathrm{b}}$ & $0.53^{\mathrm{a}}$ & $0.58^{\mathrm{a}}$ \\
\hline Vitamin C & & & $0.78^{\mathrm{b}}$ & $0.85^{\mathrm{b}}$ & $0.77^{\mathrm{b}}$ & $0.78^{b}$ \\
\hline Total polyphenols & & & & $0.61^{b}$ & $0.88^{b}$ & $0.87^{\mathrm{b}}$ \\
\hline Total flavonoids & & & & & $0.58^{\mathrm{a}}$ & $0.56^{\mathrm{a}}$ \\
\hline $\mathrm{AC}(\mathrm{DPPH})$ & & & & & & $0.98^{\mathrm{b}}$ \\
\hline
\end{tabular}

$A C(D P P H)$ Antioxidant capacity (DPPH), $A C\left(A B T S^{+}\right)$Antioxidant capacity $\left(\mathrm{ABTS}^{+}\right),{ }^{\mathrm{a}}$ significant at $5 \%$ level, ${ }^{\mathrm{b}}$ significant at $1 \%$ level, $(n=3)$ 
caffeic acid, chlorogenic acid, ferulic acid, sinapic acid, $p$-coumaric acid, rutin, naringenin, kaempferol, isoquercetin, myricetin, apigenin, catechin, quercetin, and hyperoside were identified in A. gangeticus. Across the compounds, seven compounds were identified as cinnamic acids, nine compounds were identified as benzoic acids, and nine compounds were identified as flavonoids compounds. In the previous study, 24 flavonoids and phenolic acids were identified in the leaves of red and green color amaranth (A. tricolor and A. lividus) [11]. Khanam et al. [48] and Khanam \& Oba [70] identified 16 phenolic and flavonoid compounds such as syringic acid, vanillic acid, $m$-coumaric acid, gallic acid, salicylic acid, $p$-hydroxybenzoic acid, ellagic acid, caffeic acid, trans-cinnamic acid, chlorogenic acid, rutin, ferulic acid, $p$-coumaric acid, sinapic acid, hyperoside, and isoquercetin in green and red amaranths. In the stalks, leaf, sprouts, flowers, and the seed of A. caudatus, A. cruentus, and $A$. hypochondriacus, eleven phenolics including gallic acid, chlorogenic acid, ferulic acid, $\beta$-resorcylic acid, gentisic acid, salicylic acid, protocatechuic acid, ellagic acid, rutin, quercetin, and kaempferol were detected [71]. Eight phenolics like $p$-hydroxybenzoic acid, gallic acid, vanillic acid, $p$-coumaric acid, ferulic acid, cinnamic acids, caffeic acids, syringic acids, vitexin, rutin, and isovitexin were reported in A. cruentus seeds and sprouts [72]. Across the three main classes of phenolics, the most prominent compounds were identified in four advance lines of $A$. gangeticus genotypes in the following order: benzoic acids > cinnamic acids > flavonoids.

The most available phenolic acids were salicylic acids. The rest of the benzoic acids were identified in the following order: ellagic acid $<$ syringic acid $<\beta$-resorcylic acid $p$-hydroxybenzoic acid $<$ gentisic acid $<$ protocatechuic acid < vanillic acid < gallic acid. We obtained much greater benzoic acid content in the A. gangeticus genotype LS7 and LS9 compared to the results of the benzoic acid content of green amaranth of our previous study [11] and the results of the benzoic acid content of A. tricolor [48]. The maximum salicylic acid, vanillic acid, gallic acid, gentisic acid, $\beta$-resorcylic acid, syringic acid, and ellagic acid were obtained from the genotype LS7 followed by the genotype LS9. The genotype LS9 exhibited the maximum protocatechuic acid and $p$-hydroxybenzoic acid followed by LS7. Hence, the selected advance genotypes LS7 and LS9 could be considered as high benzoic acid profiles enrich genotypes. These two genotypes could be directly used as benzoic acid profiles enrich cultivars.

Chlorogenic acid was identified as the most pronounced compound within cinnamic acids followed by trans-cinnamic acid, sinapic acid, and ferulic acid. A. gangeticus genotypes demonstrated ample cinnamic acids. Seven cinnamic acids obtained from the genotype LS7 and LS9 were much greater in comparison with the results of cinnamic acids in A. tricolor [48]. The maximum trans-cinnamic acid, chlorogenic acid, sinapic acid, ferulic acid, and $p$-coumaric acid were observed in LS7. The maximum $m$-coumaric acid and caffeic acid were reported in LS9. Seven cinnamic acids found in the current investigation were much greater in comparison to the seven cinnamic acids of green amaranth of our previous study [11]. The selected advance genotypes LS7 and LS9 could be considered as high cinnamic acid profiles enrich genotypes. These two genotypes could be directly used as cinnamic acids acid profiles enrich cultivars.

In this study, A. gangeticus genotypes demonstrated ample flavonoids such as myricetin, rutin, naringenin, isoquercetin, quercetin, kaempferol, apigenin, catechin, and hyperoside which were much greater in comparison to nine flavonoid compounds of green amaranth of our previous study [11]. LS7 demonstrated the maximum myricetin, rutin, naringenin, isoquercetin, quercetin, kaempferol, apigenin, catechin, and hyperoside. Quercetin and hyperoside of $A$. gangeticus accessions were greater in comparison to the content of quercetin and hyperoside reported in A. tricolor [48]. Hence, the selected advance accession LS7 could be considered as high flavonoids profiles enrich accession. This accession could be directly used as flavonoids profiles enrich cultivar.

LS7 demonstrated the maximum TCA, TBA, TPI, TPA, and TF. The TPI, TF, and TPA of A. gangeticus accessions were much pronounced in comparison to the content of $A$. tricolor [48]. Cinnamic acid was synthesized in the tissues of plants from the most widely available phenylalanine [73]. In the tissue of plants, although glycoside derivatives are the types of flavonoids which are most available and also occur as aglycone. Across total phenolics, $60 \%$ are represented as flavonoids [74]. Naturally, the most available flavonoids in the plants are flavonols and quercetin glycosides [74]. Different genotypes of the Cichorium spinosum exhibited significant differences in flavonoids and phenolic acid profiles [75].

In this study, considerable phenolics, such as gallic acid, protocatechuic acid, salicylic acid, vanillic acid, trans-cinnamic acid, $p$-hydroxybenzoic acid, gentisic acid, $\beta$-resorcylic acid, ellagic acid, syringic acid, caffeic acid, chlorogenic acid, $m$-coumaric acid, ferulic acid, sinapic acid, $p$-coumaric acid, rutin, isoquercetin, naringenin, quercetin, kaempferol, myricetin, catechin, apigenin, and hyperoside were identified in A. gangeticus genotypes. The reported results of Khanam \& Oba [70] were corroborative to the results of our present study. They obtained greater vanillic acid, salicylic acid, gallic acid, ellagic acid, syringic acid, trans-cinnamic 
acid, $m$-coumaric acid, $p$-hydroxybenzoic acid, chlorogenic acid, caffeic acid, isoquercetin, ferulic acid, rutin, and $p$-coumaric acid in A. tricolor genotypes in comparison with green amaranth. In this study, obtained vanillic acid, salicylic acid, $p$ - hydroxybenzoic acid, gallic acid, $m$-coumaric acid, syringic acid, trans-cinnamic acid, ellagic acid, chlorogenic acid, caffeic acid, $p$-coumaric acid, hyperoside, ferulic acid, and rutin were greater in comparison with the phenolic acids of A. tricolor [48]. A. gangeticus accession LS7 contained high flavonoids including rutin, naringenin, isoquercetin, quercetin, myricetin, kaempferol, apigenin, catechin, and hyperoside. The accessions LS7 and LS9 exhibited high phenolic profile including gallic acid, protocatechuic acid, vanillic acid, salicylic acid, trans-cinnamic acid, $p$-hydroxybenzoic acid, gentisic acid, ellagic acid, $\beta$-resorcylic acid, syringic acid, caffeic acid, $m$-coumaric acid, chlorogenic acid, ferulic acid, sinapic acid, $p$-coumaric acid. The accessions LS7 and LS9 might be utilized as high-yielding cultivars containing ample phenolics. It revealed from this study that the genotypes LS7 and LS9 containing abundant phenolic profiles demand deep and elaborate pharmacological study to find out the new insight of this crop.

TP, pro-vitamin A, vitamin C, AC, and TF differed significantly among the advance lines of $A$. gangeticus. The accession LS7 showed the maximum pro-vitamin A, vitamin C, TP, TF, AC (DPPH assay), and AC (ABTS assay) followed by LS9. Khanam \& Oba [70] reported higher TP, TF, and AC content in A. tricolor genotypes in comparison with green amaranth which was corroborative to our present study. The A. gangeticus advance lines LS7 and LS9 contained high pro-vitamin A, vitamin $\mathrm{C}$, TP, TF, and AC compared to the accession LS3 and LS5. Hence, these antioxidant constituents of $A$. gangeticus advance lines could be an important parameter for consumers, playing a vital contribution for quenching of ROS, protecting aging, and several degenerative human diseases $[18,20]$. Our result revealed that the A. gangeticus accessions had an abundant source of antioxidant constituents such as pro-vitamin A, vitamin $\mathrm{C}, \mathrm{TF}, \mathrm{TF}$, and $\mathrm{AC}$ across leafy vegetables that has important free radical-scavenging activity [21].

In this study, considerable antioxidant constituents such as pro-vitamin $\mathrm{A}$, vitamin $\mathrm{C}, \mathrm{TP}, \mathrm{TF}$, and $\mathrm{AC}$ were found in the A. gangeticus accessions. The findings of the present study were corroborative to the findings of TP, TP, and AC of A. tricolor [70]. AC (ABTS), TF, and AC (DPPH) obtained in this study corroborated with the findings of $A$. tricolor [48] whereas, TP obtained in this study were much greater in comparison to TP of A. tricolor [48]. Vitamin C obtained from $A$. gangeticus accessions was much greater in comparison to vitamin $\mathrm{C}$ of different Amaranthus species [45]. The present results showed that the red color $A$. gangeticus genotypes exhibited 2 to 3 -fold higher $\beta$ carotene in comparison with the $\beta$-carotene of green color $A$. gangeticus [76]. $\beta$-carotene of red color $A$. gangeticus was 2 to 3 -fold higher than the $\beta$-carotene of $A$. caudatus leaves [20]. A. hypochondriacus exhibited the maximum TF, TP, and TAC (ORAC and FRAP methods) in comparison with A. caudatus [71]. Additionally, they noted the maximum TF, TP, and TAC (FRAP) in comparison with sprouts, seed, flowers, and stalks. The procedures of determination and extraction and standards differed from the present methodology; hence, it's tedious to compare the current findings with their results. The accessions LS7 and LS9 demonstrated high phenolic profiles, antioxidant constituents such as pro-vitamin A, vitamin $\mathrm{C}, \mathrm{TP}, \mathrm{TF}$, and AC. The accessions LS7 and LS9 could be used as antioxidant profiles enriched high-yielding varieties. It revealed from the study that these two accessions could offer huge prospects for feeding the antioxidant-deficient community.

Pro-vitamin A and vitamin $\mathrm{C}$ had significant positive interrelationships with vitamins, TP, TF, AC (DPPH and ABTS) that signify that both pro-vitamin A and vitamin $\mathrm{C}$ exhibited good antioxidant potentiality. The results of the present study corroborated with the results of our earlier study of drought and salt-stressed A. tricolor [2224, 28]. The significant correlations among TP, TF, AC (DPPH and ABTS) were observed that indicated high potential antioxidant activity of TP and TF in A. gangeticus. The correlations of TP and TF, versus AC (FRAP) in salt-stressed purslane [77], were corroborative to our present findings. Similarly, AC (ABTS) was significantly associated with $\mathrm{AC}(\mathrm{DPPH})$ that validated the estimation of antioxidant activity of two different methods in $A$. gangeticus.

\section{Conclusions}

Twenty-five flavonoids and phenolic acids such as $p$ hydroxybenzoic acid, salicylic acid, protocatechuic acid, vanillic acid, gentisic acid, gallic acid, $\beta$-resorcylic acid, ellagic acid, syringic acid, chlorogenic acid, $m$-coumaric acid, trans-cinnamic acid, caffeic acid, ferulic acid, sinapic acid, $p$-coumaric acid, naringenin, rutin, isoquercetin, kaempferol, catechin, hyperoside, myricetin, apigenin, and quercetin were identified in the A. gangeticus genotypes. A. gangeticus genotype LS7 and LS9 had abundant phenolic acids, flavonoids, antioxidant constituents, and antioxidant potentiality. It revealed from the correlation study that all antioxidant compositions of $A$. gangeticus exhibited high antioxidant potentiality. It revealed from the study that two $A$. gangeticus genotypes had excellent sources of antioxidants components capable of quenching ROS. It revealed from this study that data obtained from advance lines of $A$. gangeticus genotypes contribute to the scientists to evaluate pharmacologically active constituents. 


\section{Abbreviations}

ANOVA: Analysis of variance; ABTS: 2,2'-azino-bis-(3-ethylbenzothiazoline-6sulphonic acid); AAS: Atomic absorption spectrophotometry; DPPH: 2,2diphenyl-1-picrylhydrazyl; DHA: Dehydroascorbate; DMRT: Duncan's Multiple Range Test; DTT: Dithiothreitol; DW: Dry weight; FW: Fresh weight; FRAP: Ferric reducing antioxidant power; GAE: Gallic acid equivalent; HCl: Hydrochloric acid; HPLC-UV: High-performance liquid chromatographyultra violet; LC-MS-ESI: Liquid chromatography-mass spectroscopyelectrospray ionization; ORAC: Oxygen radical absorbance capacity; RCBD: Completely randomized block design; RE: Rutin equivalent; ROS: Reactive oxygen species; SD: Standard deviation; TAC: Total antioxidant capacity; TEAC: Trolox equivalent antioxidant capacity; TFC: Total flavonoid content; TPC: Total polyphenol content; TPI: Total phenolic index

\section{Acknowledgments}

None.

\section{Authors' contributions}

US conceptualized and conducted the experiments, analyzed the data, helped with the experimental design, and prepared and revised the manuscript. SO revised the manuscript and give valuable suggestions. All authors read and approved the final manuscript.

\section{Funding}

No funding was received.

\section{Availability of data and materials}

All data generated or analyzed during this study are included in this article and available from the corresponding author on reasonable request.

\section{Ethics approval and consent to participate}

Not applicable.

\section{Consent for publication}

Not applicable.

\section{Competing interests}

The authors declare that they have no competing interests.

\section{Author details}

'Department of Genetics and Plant Breeding, Faculty of Agriculture, Bangabandhu Sheikh Mujibur Rahman Agricultural University, Gazipur-1706, Bangladesh. ${ }^{2}$ Laboratory of Field Science, Faculty of Applied Biological Sciences, Gifu University, Yanagido 1-1, Gifu, Japan.

\section{Received: 5 May 2020 Accepted: 13 October 2020}

\section{Published online: 02 November 2020}

\section{References}

1. Sarker U, Islam MT, Rabbani MG, Oba S. Genotypic variability for nutrient, antioxidant, yield and yield contributing traits in vegetable amaranth. J Food Agri Environ. 2014;12:168-74.

2. Sarker U, Islam MT, Rabbani MG, Oba S. Variability, heritability and genetic association in vegetable amaranth (Amaranthus tricolor). Span J Agric Res. 2015a;13:1-8 https://doi.org/10.5424/sjar/2015132-6843.

3. Sarker U, Islam MT, Rabbani MG, Oba S. Genotype variability in composition of antioxidant vitamins and minerals in vegetable amaranth. Genetika. 2015b;47:85-96

4. Sarker U, Islam MT, Rabbani MG, Oba S. Genetic variation and interrelationship among antioxidant, quality and agronomic traits in vegetable amaranth. Turk J Agric For. 2016;40:526-35.

5. Sarker U, Islam MT, Rabbani MG, Oba S. Genotypic diversity in vegetable amaranth for antioxidant, nutrient and agronomic traits. Indian J Genet PI Breed. 2017;77:173-6.

6. Chakrabarty T, Sarker U, Hasan M, Rahman MM. Variability in mineral compositions, yield, and yield contributing traits of stem amaranth (Amaranthus lividus). Genetika. 2018;50:995-1010

7. Sarker U, Oba S. Protein, dietary fiber, minerals, antioxidant pigments and phytochemicals, and antioxidant activity in selected red morph Amaranthus leafy vegetable. PLoS One. 2019a;14:0222517 https://doi.org/10.1371/journal. pone.0222517.
8. Sarker U, Oba S. Nutraceuticals, antioxidant pigments, and phytochemicals in the leaves of Amaranthus spinosus and Amaranthus viridis weedy species. Sci Rep. 2019b;9:20413 https://doi.org/10.1038/s41598-019-50977-5.

9. Sarker U, Islam MT, Rabbani MG, Oba S. Variability in total antioxidant capacity, antioxidant leaf pigments and foliage yield of vegetable amaranth. J Integrative Agric. 2018a;17:1145-53.

10. Sarker U, Islam MT, Rabbani MG, Oba S. Antioxidant leaf pigments and variability in vegetable amaranth. Genetika. 2018b;50:209-20.

11. Sarker U, Oba S. Antioxidant constituents of three selected red and green color Amaranthus leafy vegetable. Sci Rep. 2019c;9:18233 https://doi.org/10. 1038/s41598-019-52033-8.

12. Sarker U, Islam MT, Rabbani MG, Oba S. Phenotypic divergence in vegetable amaranth for total antioxidant capacity, antioxidant profile, dietary fiber, nutritional and agronomic traits. Acta Agric Scand Section B- Soil Plant Sci. 2018c;68:67-76.

13. Sarker U, Hossain MM, Oba S. Nutritional and antioxidant components and antioxidant capacity in green morph Amaranthus leafy vegetable. Sci Rep. 2020;10:1336 https://doi.org/10.1038/s41598-020-57687-3.

14. Sarker U, Oba S, Daramy MA. Nutrients, minerals, antioxidant pigments and phytochemicals, and antioxidant capacity of the leaves of stem amaranth. Sci Rep. 2020;10:3892 https://doi.org/10.1038/s41598-020-60252-7.

15. Sarker U, Oba S. Nutrients, minerals, pigments, phytochemical, and radical scavenging activity in Amaranthus blitum leafy vegetable. Sci Rep. 2020a;10: 3868 https://doi.org/10.1038/s41598-020-59848-w.

16. Dusgupta N, De B. Antioxidant activity of some leafy vegetables of India: a comparative study. Food Chem. 2007;101:471-4

17. Isabelle M, Lee BL, Lim MT, Koh WP, Huang D, Ong CN. Antioxidant activity and profiles of common fruits in Singapore. Food Chem. 2010;123:77-84.

18. Repo-Carrasco-Valencia R, Hellstrom JK, Pihlava JM, Mattila PH. Flavonoids and other phenolic compounds in Andean indigenous grains: quinoa (Chenopodium quinoa), kaniwa (Chenopodium pallidicaule) and kiwicha (Amaranthus caudatus). Food Chem. 2010;120:128-33.

19. Steffensen SK, Rinnan A, Mortensen AG, Laursen B, Troiani RM, Noellemeyer EJ, Janovska D, Dusek K, Delano-Frier J, Taberner A, Christophersen C, Inge $S$, Fomsgaard IS. Variations in the polyphenol content of seeds of field grown Amaranthus genotypes. Food Chem. 2011;129:131-8.

20. Venskutonis PR, Kraujalis P. Nutritional components of amaranth seeds and vegetables: a review on composition, properties, and uses. Comp Rev Food Sci Food Saf. 2013;12:381-412.

21. Cai Y, Sun M, Corke $H$. Antioxidant activity of betalains from plants of the Amaranthaceae. J Agril Food Chem. 2003;51:2288-94.

22. Sarker U, Islam MT, Oba S. Salinity stress accelerates nutrients, dietary fiber, minerals, phytochemicals and antioxidant activity in Amaranthus tricolor leaves. PLoS One. 2018;13:0206388 https://doi.org/10.1371/journal.pone. 0206388

23. Sarker U, Oba S. Augmentation of leaf color parameters, pigments, vitamins, phenolic acids, flavonoids and antioxidant activity in selected Amaranthus tricolor under salinity stress. Sci Rep. 2018a;8:12349 https://doi.org/10.1038/ s41598-018-30897-6.

24. Sarker U, Oba S. Salinity stress enhances color parameters, bioactive leaf pigments, vitamins, polyphenols, flavonoids and antioxidant activity in selected Amaranthus leafy vegetables. J Sci Food Agric. 2019d;99:2275-84 https://doi.org/10.1002/jsfa.9423.

25. Sarker U, Oba S. Response of nutrients, minerals, antioxidant leaf pigments, vitamins, polyphenol, flavonoid and antioxidant activity in selected vegetable amaranth under four soil water content. Food Chem. 2018b;252: 72-83.

26. Sarker U, Oba S. Drought stress effects on growth, ROS markers, compatible solutes, phenolics, flavonoids, and antioxidant activity in A. tricolor. Appl Biochem Biotechnol. 2018c;186:999-1016 https://doi.org/10.1007/s12010018-2784-5.

27. Sarker U, Oba S. Catalase, superoxide dismutase, and ascorbate-glutathione cycle enzymes confer drought tolerance of Amaranthus tricolor. Sci Rep. 2018d:8:16496 https://doi.org/10.1038/s41598-018-34944-0.

28. Sarker U, Oba S. Drought stress enhances nutritional and bioactive compounds, phenolic acids and antioxidant capacity of Amaranthus leafy vegetable. BMC Plant Biol. 2018e;18:258 https://doi.org/10.1186/s12870-0181484-1.

29. Rajan S, Markose BL. Horticultural Science Series-6. In: Peter KMV, editor. Propagation of horticultural crops. New Delhi: New India Publishing Agency; 2007. p. 201-320. 
30. Sani HA, Rahmat A, Ismail M, Rosli R, Endrini S. Potential anticancer effect of red spinach (Amaranthus gangeticus) extract. Asia Pacific J Clinical Nutri. 2004;13:396-400.

31. Mohammadinejad R, Shavandi A, Raje DS, et al. Plant molecular farming: production of metallic nanoparticles and therapeutic proteins using green factories. Green Chem. 2019;21:1845-65.

32. Manach C, Scalbert A, Morand C, Remesy C, Jimenez L. Polyphenols: food sources and bioavailability. American J Clinical Nutri. 2004;79:727-47.

33. Leri M, Scuto M, Ontario ML, Calabrese V, Calabrese EJ, Bucciantini M, Stefani M. Healthy effects of plant polyphenols: molecular mechanisms. Int J Mol Sci. 2020;21:1250.

34. Tohidi B, Rahimmalek M, Arzani A. Essential oil composition, total phenolic flavonoid contents, and antioxidant activity of Thymus species collected from different regions of Iran. Food Chem. 2017;220:153-61.

35. Thaipong K, Boonprakob U, Crosby K, Cisneros-Zevallos L, Byrne DH. Comparison of ABTS, DPPH, FRAP, and ORAC assays for estimating antioxidant activity from guava fruit extracts. J Food Compos Anal. 2006;19: 669-75.

36. Kartika H, Li QX, Wall MM, Nakamoto ST, Iwaoka WT. Major phenolic acids and total antioxidant activity in Mamaki leaves, Pipturus albidus. J Food Sci. 2007;72:696-701.

37. Namiki M. Antioxidants/anti-mutagens in food. Critical Rev Food Sci Nutri. 1990;29:273-300

38. Cartea ME, Francisco M, Soengas P, Velasco P. Phenolic compounds in Brassica vegetables. Mol. 2011;16:251-28 https://doi.org/10.3390/ molecules16010251.

39. Maas JL, Galletta GJ, Stoner GD. Ellagic acid, an anticarcinogen in fruits, especially in strawberries: a review. HortSci. 1991;26:10-4.

40. Amin I, Norazaidah Y, Emmy Hainida Kl. Antioxidant activity and phenolic content of raw and blanched Amaranthus species. Food Chem. 2006;94:4752.

41. Rashad MMI, Sarker U. Genetic variations in yield and yield contributing traits of green amaranth. Genetika. 2020;52:391-404.

42. Sarker U, Oba S. Nutritional and bioactive constituents and scavenging capacity of radicals in Amaranthus hypochondriacus. Sci Rep. 2020b. (accepted). https://doi.org/10.1038/s41598-020-71714-3.

43. Sarker U, Oba S. Phenolic profiles and antioxidant activities in selected drought-tolerant leafy vegetable amaranth. Sci Rep. 2020c. (accepted). https://doi.org/10.1038/s41598-020-71727-y.

44. Sarker U, Hossain MN, labal MA, Oba S. Bioactive components and radical scavenging activity in selected advance lines of salt-tolerant vegetable amaranth. Front Nutr. 2020d; (accepted).

45. Jimenez-Aguilar DM, Grusak MA. Minerals, vitamin C, phenolics, flavonoids and antioxidant activity of Amaranthus leafy vegetables. J Food Compos Anal. 2017:58:33-9.

46. Sarker U, Oba S. Leaf pigmentation, its profiles and radical scavenging activity in selected Amaranthus tricolor leafy vegetables. Sci Rep. 2020e. (accepted). https://doi.org/10.1038/s41598-020-66376-0.

47. Sarker $\mathrm{U}, \mathrm{Oba} \mathrm{S}$. The response of salinity stress-induced $A$. tricolor to growth anatomy, physiology, non-enzymatic and enzymatic antioxidants. Front Plant Sci. 2020f;11:559876. https://doi.org/10.3389/fpls.2020.559876.

48. Khanam UKS, Oba S, Yanase E, Murakami Y. Phenolic acids, flavonoids and total antioxidant capacity of selected leafy vegetables. J Functional Foods. 2012;4:979-87

49. Hasan-Ud-Daula M, Sarker U. Variability, heritability, character association, and path coefficient analysis in advanced breeding lines of rice (Oryza sativa L.). Genetika. 2020;52:711-26.

50. Hasan MJ, Kulsum MU, Majumder RR, Sarker U. Genotypic variability for grain quality attributes in restorer lines of hybrid rice. Genetika. 2020; (accepted).

51. Herrmann KM. The shikimic pathway: early step in the biosynthesis of aromatic compounds. Plant Cell. 1995;7:907-19.

52. Ganapati RK, Rasul MG, Mian MAK, Sarker U. Genetic variability and character association of T-Aman rice (Oryza sativa L.). Intl J Plant Biol Res. 2014;2:1-4.

53. Ali MA, Sarker U, MAK M, Islam MA, Fatema-Tuj-Johora. Estimation of genetic divergence in boro rice (Oryza sativa L.). Intl J BioRes. 2014;16:28-36.

54. Karim D, Sarker U, Siddique MNA, Mian MAK, Hasnat MZ. Variability and genetic parameter analysis in aromatic rice. Int J Sustain Crop Prod. 2007;2: $15-8$.
55. Karim D, Sarker U, Siddique MNA, Mian MAK, Hasnat MZ. Phenotypic and genotypic correlation co-efficient of quantitative characters and character association of aromatic rice. J BioSci Agric Res. 2014;1:34-46.

56. Rai PK, Sarker U, Roy PC, Islam AKMS. Character association in $\mathrm{F}_{4}$ generation of rice (Oryza sativa L.). Bangladesh J PI Breed Genet. 2013;26:39-44.

57. Biswas PS, Sarker U, Bhuiyan MAR, Khatun S. Genetic divergence in cold tolerant irrigated rice (Oryza sativa L.). The Agriculturists. 2006;4:15-20.

58. Sarker U, Mian MAK. Genetic variations and correlations between floral traits in rice. Bangladesh J Agril Res. 2004;29:553-8.

59. Sarker U, Mian MAK. Genetic variability, character association and path analysis for yield and its components in rice. J Asiat Soc Bangladesh Sci. 2003;29:47-54

60. Sarker U, Biswas PS, Prasad B, Mian MAK. Correlated response, relative selection efficiency and path analysis in cold tolerant rice. Bangladesh J PI Breed Genet. 2001;14:33-6.

61. Nath JK, Sarker U, Mian MAK, Hossain T. Genetic divergence in T. Aman rice. Annals Bangladesh Agric. 2008;12:51-60.

62. Hasan MR, Sarker U, Mian MAK, Hossain T, Mahmud MNH. Genetic variation in micronutrient dense rice and its implication in breeding for higher yield. Eco-friendly Agril J. 2012;5:175-82.

63. Hasan MR, Sarker U, Islam MR, Mahmud MNH. Genetic diversity in micronutrient dense rice and its implication in breeding program. Ecofriendly Agril J. 2012;5:183-5.

64. Rahman MH, Sarker U, Main MAK. Assessment of variability of floral and yield traits; II maintainer lines of rice. Ann Bangladesh Agric. 2007;11:95-102.

65. Rahman MH, Sarker U, Main MAK. Assessment of variability of floral and yield traits; I restorer lines of rice. Ann Bangladesh Agric. 2007;11:87-94.

66. Biswas A, Sarker U, Banik BR, Rohman MM, Mian MAK. Genetic divergence study in salinity stress tolerance maize (Zea mays L.). Bangladesh J Agril Res. 2014;39:621-30

67. Azam MG, Sarker U, Mahmud JA, Maniruzzam M, Banik BR. Genetic variability of yield and its contributing characters of CIMMYT maize inbreds in stress condition. Bangladesh J Agril Res. 2014;39:419-26.

68. Azam MG, Sarker U, Mian MAK, Banik BR, Talukder MZA. Genetic divergence on quantitative characters of exotic maize inbreds (Zea mays L.). Bangladesh J PI Breed Genet. 2013;26:09-14.

69. Talukder MZA, Sarker U, Harun-Or-Rashid, Mian MAK, Zakaria M. Genetic diversity of coconut (Cocos nucifera L.) in Barisal Region. Ann Bangladesh Agric. 2015;19:13-21.

70. Khanam UKS, Oba S. Bioactive substances in leaves of two amaranth species, Amaranthus tricolor and A. hypochondriacus. Canadian J PI Sci. 2013; 93:47-58

71. Li H, Deng Z, Liu R, Zhu H, Draves J, Marcone M, Sun Y, Tsao R. Characterization of phenolics, betacyanins and antioxidant activities of the seed, leaf, sprout, flower and stalk extracts of three Amaranthus species. J Food Compos Anal. 2015:37:75-81.

72. Pasko P, Sajewicz M, Gorinstein S, Zachwieja Z. Analysis of selected phenolic acids and flavonoids in Amaranthus cruentus and Chenopodium quinoa seeds and sprouts by HPLC. Acta Chromatogr. 2008;20:661-72.

73. Robbins RJ. Phenolic acids in foods: an overview of analytical methodology. J Agril Food Chem. 2003;51:2866-87.

74. Harborne JB, Williams CA. Advances in flavonoid research since 1992. Phytochem. 2000;55:481-504

75. Petropoulos SA, Levizou E, Ntatsi G, Fernandes A, Petrotos K, Akoumianakis $K$, Barros L, Isabel CFRF. Salinity effect on nutritional value, chemical composition, and bioactive compounds content of Cichorium spinosum L. Food Chem. 2017:214:129-36.

76. Raju M, Varakumar S, Lakshminarayana R, Krishnakantha PT, Baskaran V. Carotenoid composition and vitamin a activity of medicinally important green leafy vegetables. Food Chem. 2007;101:1598-605.

77. Alam MA, Juraimi AS, Rafii MY, Hamid AA, Aslani F, Alam MZ. Effects of salinity and salinity-induced augmented bioactive compounds in purslane (Portulaca oleracea L.) for possible economical use. Food Chem. 2015;169: 439-47.

\section{Publisher's Note}

Springer Nature remains neutral with regard to jurisdictional claims in published maps and institutional affiliations. 